\title{
Analisis Wacana Sara Mills Tentang Kekerasan Perempuan dalam Rumah Tangga Studi Terhadap Pemberitaan Media Kumparan
}

\author{
Siti Nur Alfia Abdullah
}

UIN Sunan Kalijaga Yogyakarta

alfia10nuralfiaabdullab@,gmail.com

\begin{abstract}
Violence against women in domestic life that is carried out by husbands to wives is now increasingly being discussed as a global issue, online coil media as a channel for people's aspirations as well as reporting on current phenomena, not missing out on presenting the news. The focus of this study looks at how the media perspective in preaching the problem using descriptive research methods through the approach to critical discourse analysis model sara mills, which was published in online coil media by taking five beadlines of violence against women, namely, "Frequently questioned after leaving the house, husband persecutes wife to death, not yet 3 months, there were 7 cases of violence against women, a husband at sikka beat his wife until his head leaked after quarreling, because of the fight over the tv remote husband could beat his wife to bleed, mayhem wife and child using a man's knife in Pasuruan secured. The results of this study show the role of women as writing objects, because the women in the news text above always get harsh treatment in the form of quarrels, and get knives multiple times and punches to the effect of death, but on several occasions coils also show women as subjects representing himself in the writing. Thus, online media coils in reporting discourse about women have their own perspective by being able to portray women as victims described in the text, also finding women representing subjects in news texts.
\end{abstract}

Key Words: Discourse Analysis, Sara Mills, Kumparan, KDRT

\begin{abstract}
Abstrak
Kekerasan terhadap perempuan dalam kehidupan berumah tangga yang dilakukan suami kepada istri saat ini kian ramai diperbincangkan menjadi isu yang sudah mendunia, media online kumparan sebagai penyalur aspirasi rakyat serta memuat pemberitaan soal fenomena kekinian, tidak ketinggalan dalam menyajikan berita tersebut. Fokus penelitian ini melihat bagaimana perspektif media dalam memberitakan masalah tersebut dengan menggunakan metode penelitian deskriptif melalui pendekatan model analisis wacana kritis sara mills, yang dimuat pada media online kumparan dengan mengambil lima judul berita kekerasan terhadap
\end{abstract}


perempuan yakni, "Sering ditanyai usai keluar rumah, suami aniaya istri bingga tewas, Belum 3 bulan, ada 7 kasus kekerasan terhadap perempuan, Seorang suami di sikeka pukul istri hingga kepala bocor usai cekcok, Gara-gara rebutan remote tv suami tega hajar istri hingga berdarah, Aniaya istri dan anak pakai pisau pria di pasuruan diamankan. Hasil penelitian ini menunjukan peran perempuan sebagai objek tulisan, karena perempuan pada teks berita di atas selalu mendapatkan perlakuan kasar dalam bentuk adu mulut, dan mendapat tusukan pisau berulan kali serta pukulan hingga berakibat pada kematian, namun dalam beberapa kesempatan kumparan juga menampilkan perempuan sebagai subjek yang merepresentasikan dirinya dalam tulisan tersebut. Dengan demikian, media online kumparan dalam memberitakan wacana soal perempuan memiliki persepktif tersendiri dengan bisa melukiskan perempuan sebagai korban yang dijelaskan dalam teks, juga mendapati perempuan mewakili subjek dalam teks berita.

Kata Kunci : Analisis Wacana, Sara Mills, Kumparan, KDRT

\section{A. Pendahuluan}

Fenomena yang nyata terlihat saat ini adalah isu gender yang dari waktu ke waktu, menjadi perhatian penting dari semua kasus, realitasnya perbedaan gender memberi dampak pada perbedaan status, tanggung jawab dan peran antara perempuan dan laki-laki, yang pada akhirnya menimbulkan ketidakadilan dalam rana diskriminasi maupun penindasan terhadap perempuan. Problem ketidakadilan gender ini semakin meluas dan sulit terpecahkan. Diskriminasi yang dialami perempuan terjadi dalam berbagai aspek kehidupan, baik dalam lingkungan publik, bidang pendidikan, hukum, kesehatan, politik, ekonomi, bahkan dalam kehidupan berkeluarga sekalipun.

Secara bahasa kata "gender" berasal dari bahasa Inggris, atau "Geschlecht” (bahasa Jerman), "Genre” (bahasa Perancis), "Genero" (bahasa Spanyol), dan dalam bahasa latin disebut generare, memiliki arti jenis, ras dan kelas atau prokrease. Dalam pandangan sosilogi, relasi gender dipahami sebagai sekumpuluan aturan-aturan, tradisi dan hubungan timbal balik dalam perilaku sosial budaya masyarakat yang menentukan batas-batas maskulin ( sifat yang dianggap kelaki-lakian) dan batas feminis (sifat yang dianggap kepermpuanan). Artinya bahwa gender dipahami sebagai penentuan feminitas dan maskulinitas, yang dikonstruk secara sosio kultural. ${ }^{1}$

Setiap negara memiliki sistem hukum yang mengacu kepada keberlangsungan hidup rakyat yang sejahtera. Di Indonesia, sesuai dengan Falsafah Pancasila dan aturan UUD Negara Republik Indonesia Tahun 1945, memutuskan bahwa setiap warga negara Indonesia berhak mendapatkan

${ }^{1}$ Siti Zubaedah, Mengurai Problematika Gender Agama, Volume. 5, Cetekan ke-2, (Purwokerto: YINYANG, Jurnal Studi Gender \& Anak, Juli-Desember 2010), 2 
kebebasan serta rasa aman dari segala bentuk kejahatan dan tindak kekerasan, yang bisa mengancam jiwa dan raganya. Apalagi kekerasan yang dilakukan dalam rumah tangga, yang sebagian besar korbannya adalah perempuan, bentuk penyiksaan, perlakuan kasar yang merendahkan derajat serta martabat perempuan yang dilakukan oleh suami dalam kehidupan berkeluarga sangat dikecam oleh agama, UU serta aturan-aturan hidup masyarakat yang menjunjung keharmonisan hidup.

Kekerasan yang dilakukan oleh suami kepada istri menjadi kasus yang paling banyak ditemui dan mendapat perhatian penting, berbeda dengan kasus yang lain, jika ditinjau kembali dalam hubungan berumah tangga sebelumnya ada suami dan istri yang berjanji untuk saling menyayangi dalam ikatan akad nikah yang suci, namun dalam proses menjalin bahtera pernikahan permasalahan kekerasan dalam rumah tangga ikut menghiasi kehidupan tersebut.

Pada dasarnya Islam menekankan pada keadilan serta kesejahteraan antara laki-laki dan perempuan, termasuk dalam kehidupan rumah tangga serta pemenuhan kebutuhan seksual suami-istri. Namun tetap saja, kenyataannya laki-laki lebih bersifat hegemoni dalam pengambilan keputusan terhadap lawannya, sementara perempuan dituntut untuk bersikap menerima, tentang apa yang sudah ditentukan padanya. ${ }^{2}$

Jelas bahwa kekerasan terhadap perempuan menjadi isu global yang mendunia, tindakan ini merupakan bentuk pelanggaran Hak Asasi Manusia, pada tahun 2011 data yang dikeluarkan oleh UNIFEM (dana PBB untuk perempuan), menunjukan bahwa di Eropa jumlah perempuan yang mengalami kekerasan oleh pasangannya mencapai 57,9\% di Amerika Serikat $22,1 \%$, India 49\%, Banglades mencapai $60 \%$ dan di Indonesia 11,4\% dari sekitar 24 juta penduduk perempuan yang mengalami tindak kekerasan.

Seiring berjalannya waktu keberhasilan media cetak dengan visi memuat pemberitaan seputar informasi kehidupan tidak sekedar ditemui dalam kemasan media cetak, namun lebih jauh media online yang memuat berbagai informasi saat ini pun menjadi garda terdepan yang tidak luput dari akses masyarakat. Kumparan sebagai media online, sejauh ini memberitakan kurang lebih 80 kasus kekerasan yang menimpa perempuan, fokus penelitian ini akan menganalisis bagaimana media tersebut menampilkan pemberitaan soal isu kekerasan terhadap perempuan dalam kehidupan masyarakat, sehingga kita mampu melihat bagaimana peran media akan muncul dalam mempresentasikan realitas sosial.

\section{B. Metode Penelitian}

Penelitian ini menggunakan metode kepustakaan (library research) yaitu penelitian yang datanya di ambil terutama dari kepustakaan (buku,

2 Mochamad Sodik, Kesetaraan Gender Sebagai Pemenuhan Konstitusi, Volume 11, Cetakan ke-2, (Yogyakarta: Jurnal Musãwa, Juli 2012), 174 
dokumen, artikel, laporan, koran, dan lain sebagainya). Karena sumber utama data adalah kepustakaan, maka kualitas penelitian kepustakaan ini juga sangat tergantung pada kualitas dokumen- dokumen yang dikaji. Semakin otentik dokumen maka akan semakin bagus data. Semakin up to date, semakin bagus hasil penelitian ${ }^{3}$.

Peneltian ini juga bersifat deskriptif kualitatif, yakni menelaah isi teks berita, berupa simbol-simbol serta ide pokok yang muncul dalam tema suatu pemberitaan. ${ }^{4}$ Dengan menggunakan pendekatan analitik wacana kritis model Sara Mills, terhadap teks berita yang berjudul. "Sering ditanyai usai keluar rumah, suami aniaya istri hingga tewas, Belum 3 bulan, ada 7 kasus kekerasan terhadap perempuan, Seorang suami di sikka pukul istri hingga kepala bocor usai cekcok, Garagara rebutan remote to suami tega hajar istri bingga berdarab. Aniaya istri dan anak pakai pisau pria di pasuruan diamankan".

Sumber data dalam penelitian ini terbagi menjadi dua kategori, yaitu sumber primer yang penulis dapat dari pemberitaan media sosial tentang "Sering ditanyai usai keluar rumah, suami aniaya istri hingga tewas, Belum 3 bulan, ada 7 kasus kekerasan terhadap perempuan, Seorang suami di sikeka pukeul istri hingga kepala bocor usai cekcok, Gara-gara rebutan remote tv suami tega hajar istri hingga berdarah, Aniaya istri dan anak pakai pisau pria di pasuruan diamankan". Sedangkan data sekunder di dapat dari buku-buku, dokumentasi, maupun artikel di media massa, yang terkait dengan tulisan ini. ${ }^{5}$

Adapun teknik pengumpulan datanya dilakukan dengan cara observasi yakni teknik yang pertama dan paling utama dilakukan dalam penelitian dengan cara mengamati dan mencatat secara sistematis terhadap fenomena yang diselidiki atau diteliti. Teknik selanjutnya, mendapatkan hasil peneltian, yang penulis lakukan dengan cara menela'ah berita tersebut dengan pedekatan Sarah Mills juga literatur pendukung lain yang bersinggungan dengan tema pembahasan pada tulisan ini. ${ }^{6}$

\section{Literatur Review}

Dalam beberapa pencarian terhadap peneltian terdahulu mengenai berita yang dimaksud, penulis belum menemukan kajian yang spesifik membincang tentang berita tersebu, namun dalam hal penerapan model analisis Sara Mils dalam mengkaji tentang gender, penulis menemukan beberapa peneltian, misalkan; hlm. 65

${ }^{3}$ Prasetya Wirawan, Logika dan Prosedur Penelitian.( Jakarta: CV Infomedika, 2000),

${ }^{4}$ Aris Badara, Analisis Wacana: Teori, Metode dan Penerapannya Pada Wacana Media, (Jakarta : Kencana Prenada Media Group, 2013), 63.

5 Hadari Nawawi, Metode Penelitian Bidang Sosial, (Yogyakarta: Gajah Mada University Press, 1991), 95. Lihat juga, Nyoman Kutha Ratna, Metodologi Penelitian: Kajian Budaya dan Ilmu Sosial Humaniora, (Yogyakarta: Pustaka Pelajar, 2010), 94-100

${ }^{6}$ Jalaluddin Rahmat, Metode Penelitian Komunikasi, (Bandung: Remaja Rosdakarya, 1999), 83 
Peneltian berjudul Model Sara Mills Dalam Analisis Wacana Peran Dan Relasi Gender, dari Teti Sobari, dan Lilis Faridah. Dalam peneltian tersebut menela'ah wacana feminisme, tentang peran dan relasi gender perempuan hingga bagaimana perempuan ditampilkan dalam teks yang berkaitan dengan nilai dan perilaku sosial, dalam berita yang berjudul "Punya Anak Hambatan Karir Perempuan Indonesia?” yang ditulis pada Koran Republika tanggal 9 Maret 2012 dan? Metode penelitian yang digunakan adalah metode deskriptif kualitatif dengan menggunakan pendekatan analitik wacana kritis Sarah Mills.

Hasil penelitian menunjukkan bahwa penulis menampilkan perempuan sebagai subjek tulisan, karena perempuan pada teks berita di atas posisinya mendefinisikan dan ia dapat menampilkan dirinya sendiri. Sedangkan objek dari wacana tersebut adalah karir atau pekerjaan yang merupakan peran ganda yang harus dilakukan oleh seorang perempuan ketika ingin terus melanjutkan pekerjaan sambil berperan sebagai ibu rumah tangga. Dengan demikian, peran dan relasi gender dalam teks tersebut dapat menampilkan dirinya dan juga bisa berperan ganda. ${ }^{7}$

Peneltian lain juga penulis temukan dengan judul Marjinalisasi Perempuan Dalam Berita Pelecehan Seksual Surat Kabar Harian Memorandum Edisi September 2013 Dan Juli 2015: Analisis Wacana Kritis Sara Mills, dari Shella Yan Prantya. Penelitian ini mengangkat masalah mengenai marjinalisasi perempuan sebagai subjek, objek, dan pembaca berita pelecehan seksual dalam surat kabar harian Memorandum edisi September 2013 dan Juli 2015 yang dianalisis menggunakan teori analisis wacana kritis Sara Mills. Dengan tujuan untuk menghasilkan deskripsi tentang marjinalisasi perempuan sebagai subjek, objek dan pembaca pada berita tersebut. Penelitian menggunakan jenis penelitian deskriptif dalam pendekatan kualitatif.

Hasilnya salah satunya menunjukan bahwa marjinalisasi perempuan sebagai subjek berita pelecehan seksual dalam surat kabar harian Memorandum ditemukan bahwa pada data-data yang dianalisis subjek selalu ditampilkan sebagai pencerita. Dalam teks subjek dapat menampilkan dirinya sesuai dengan kepentingan dan ada yang bisa ditampilkan sebagai pencerita. Akibatnya, pihak tersebut sering ditampilkan secara baik. Marjinalisasi perempuan sebagai objek berita pelecehan seksual dalam surat kabar harian Memorandum ditemukan bahwa pada data yang dianalisis, objek selalu ditampilkan menurut perspektif pencerita. ${ }^{8}$

Dalam penerapan analsis Sara Mills, penulis juga menemukan penerapannya pada sebuah film. Sepertihalnya pada penelitian dengan judul Wacana Mengenai Human Trafficking Dalam Film "Jamila Dan Sang Presiden”, dari

7 Teti Sobari, dan Lilis Faridah, Model Sara Mills Dalam Analisis Wacana Peran Dan Relasi Gender, Volume 5, Cetakan ke-1, (Siliwangi: SEMANTIK: Jurnal Ilmiah Program Studi Pendidikan Bahasa dan Sastra Indonesia, February, 2016), 88-99

8 Shella Yan Prantya, Marjinalisasi Perempuan Dalam Berita Pelecehan Seksual Surat Kabar Harian Memorandum Edisi September 2013 Dan Juli 2015: Analisis Wacana Kritis Sara Mills, Volume 01 Cetakan ke-1, (Surabaya: Jurnal BAPADA, Tahun 2017), 1-7 
Rosa Oktaviani Tanesia. Peneltian ini bertujuan untuk mengetahui bagaimana wacana mengenai human trafficking dalam film Jamila dan Sang Presiden. Dalam penggunaan metode analisis wacana kritis model Sara Mills. Penelitian ini menemukan ketidakberpihakan peran negara kepada seorang perempuan korban human trafficking yang berdampak pada aspek moral, gender, dan makin maraknya kasus human trafficking. Kontribusi penelitian ini agar perempuan harus berjuang dengan atau tanpa bantuan pihak lain untuk bisa memperbaiki kondisi yang tidak baik ini. Di mana perempuan diperlakukan tidak adil, dieksploitasi, tidak bisa memperoleh haknya, dan dimarjinalkan. ${ }^{9}$

Dari beberapa peneltian di atas, kemudian penulis ingin menela'ah dengan menggunakan model analisis Sara Mills dalam sebuah berita, yang sedang menjadi perbincangan yakni "Sering ditanyai usai keluar rumah, suami aniaya istri hingga tewas, Belum 3 bulan, ada 7 kasus kekerasan terhadap perempuan, Seorang suami di sikeka pukul istri bingga kepala bocor usai cekcok, Gara-gara rebutan remote tv suami tega hajar istri hingga berdarah, Aniaya istri dan anak pakai pisau pria di pasuruan diamankan. Yang diberitakan oleh media Kumparan.

\section{Kajian Teori}

\section{Kekerasan Perempuan Dalam Rumah Tangga}

Pengertian tentang kekerasan dapat dilihat dari berbagai sumber, menurut Kamus Besar Bahasa Indonesia, kekerasan menyangkut dengan perihal yang berciri keras, perbuatan seseorang atau sekelompok, dalam bentuk pengrusakan fisik atau barang orang lain secara paksa, sehingga mengakibatkan orang lain cidera atau mati, dalam kamus Oxford kata kekerasan dapat dipahami kekerasan tidak secara fisik saja, namun berkaitan dengan tekanan psikis dan emosional. ${ }^{10}$ Pengertian diatas menunjukan kekerasan secara non verbal juga menjadi bagian dari tindak kejahatan.

Deklarasi PBB menjelaskan pada pasal 1 tentang kekerasan terhadap perempuan, mengandung istilah "violence against women means any act of genderbased violence that results in, or is likely to result in, physical, sexual or psychological harm or suffering to women, including threats of such acts, coercion or arbitrary deprivation of liberty, whether occurring in public or in private life". Yang berarti kekerasan terhadap perempuan merupakan bentuk perbuatan yang berdasarkan perbedaan kelamin, sehingga berakibat kesengsaraan serta penderitaan perempuan secara fisik, psikologi atau seksual, termasuk ancaman dalam

${ }_{9}$ Rosa Oktaviani Tanesia, Wacana Mengenai Human Trafficking Dalam Film "Jamila Dan Sang Presiden", Volume. 1, Cetakan ke-2, (Surabaya: Jurnal E-Komunikasi, Tahun 2013), 50-58

${ }^{10}$ Kurnia Muhajarah, Kekerasan Terhadap Perempuan Dalam Rumah Tangga Perspektif Sosio-Budaya, Hukum dan Agama, Volume. 11, Cetakan ke-2, (Semarang: SAWWA, April 2016), 129 
bagian tertentu, seperti pemaksaan atau perampasan kebebasan secara otoriter baik dalam rana publik maupun dalam kehidupan pribadi. ${ }^{11}$

Lebih lanjut dijelaskan dalam pasal 2 menyatakan ,kekerasan terhadap perempuan harus dimaknai mencakup secara keseluruhan, artinya bahwa tidak hanya terbatas pada, tindak kekerasan secara fisik, psikologis dan seksual kenyataannya yang terjadi saat ini baik dalam lingkungan keluarga dan masyarakat kekerasan dalam bentuk pemukulan, penyalahgunaan seksual atas perempuan dan anak-anak, tindak kejahatan yang berhubungan dengan perempuan, perkosaan dalam perkawinan (marital rape), praktek-praktek kekejaman tradisional pengrusakan alat kelamin perempuan terhadap perempuan, kekerasan yang berkaitan dengan hubungan suami istri diluar nikah serta eksploitasi perempuan, pembunuhan, perampokan, pelecehan dan ancaman seksual di tempat kerja dan di lembaga-lembaga pendidikan dan sebagainya, perdagangan perempuan secara paksa serta pelacuran, semuanya adalah bentuk kekerasan yang dibenarkan dan dilakukan oleh negara di manapun terjadinya.

Pada pengertian lain dalam kontek Indonesia setiap warga negara berhak mendapatkan rasa aman dan bebas dari segala bentuk kekerasan sesuai dengan falsafah Pancasila dan Undang-Undang Dasar Negara Republik Indonesia Tahun 1945. Segala bentuk kekerasan, terutama kekerasan terhadap perempuan dalam rumah tangga, merupakan pelanggaran hak asasi manusia dan kejahatan terhadap martabat kemanusiaan serta bentuk diskriminasi yang harus dihapus. Korban kekerasan dalam rumah tangga, yang kebanyakan adalah perempuan, harus mendapat perlindungan dari negara dan atau masyarakat agar terhindar dan terbebas dari kekerasan atau ancaman kekerasan, penyiksaan, atau perlakuan yang merendahkan derajat dan martabat kemanusiaan. Pembahasan tentang kekerasan dalam rumah tangga, terutama kekerasan yang dilakukan oleh suami terhadap istri, merupakan hal yang menarik untuk dikaji.

Hemat penulis, kekerasan terhadap perempuan merupakan tindak kejahatan yang menimbulkan kesengsaraan dalam menjalani kehidupan, timbul penderitaan secara fisik maupun psikologis, tindakan seperti mengecam hak asasi manusia, tidak adanya ruang dalam menyampaikan pendapat, perampasan kebebasan dalam bertindak dan berkreasi menurut aturan yang berlaku juga bentuk kecaman lain dari tindak kekerasan, keadaan ini menyebabkan perempuan yang menjadi korban tindak kekerasan menghadapi tekanan batin dan sosial

Untuk lebih jelas menurut Martin R. Haskell dan Lewis Yabslonswky Kusumah kekerasan dapat dilihat dari empat pola dibawah ini : ${ }^{12}$

\footnotetext{
${ }^{11}$ Muhammad Hasbi, Kekerasan Perempuan Dalam Wacana Agama dan Sosiologi, Volume. 15, Cetakan ke-2 (Ponorogo: Jurnal Al-Tahrir, November, 2015), 392

${ }^{12}$ Kurnia Muhajarah, Kekerasan Terbadap Perempuan Dalam Rumah Tangga Perspektif Sosio-Budaya, Hukum dan Agama, Op.cit., 131
} 
1. Kekerasan legal, adalah kekerasan yang masuk dan didukung oleh aturan hukum, misalnya kekerasan tentara yang ikut peperangan dan bentuk kekerasan yang dilakukan dibenarkan pada saat itu.

2. Kekerasan yang secara sosial memperoleh sangsi. Dalam menganalisa suatu kekerasan, sangsi sosial menjadi faktor penting dalam menilai masalah tindak kekerasan, misalnya kecaman keekrasan yang dilakukan oleh masyarakat terhadap pelaku zina, yang memperoleh dukungan sosial

3. Kekerasan rasional. Meskipun tindakan ini tidak legal, juga tidak ada hukuman sosialnya adalah kejahatan yang dipandang rasional dalam kaitannya dengan tindak kejahatan, misalnya pembunuhan yang terorganisasi.

4. Kekerasan yang tidak berperasaan, "Irrational Violence" kekerasan jenis ini berawal dari gangguan psikis seseorang yang memancingnya untuk berbuat kekerasan pada saat tertentu yang merupakan bagian dari ekspresi hidup yang dirasakan untuk memperlihatkan motivasi tindakannya, kejahatan jenis ini digolongkan dalam "Raw Violence", yaitu kejahatan tidak terprovokasi melainkan gejolak dari dalam jiwa.

Dalam pandangan Harkristuti Harkrisnowo kekerasan terhadap perempuan adalah setiap bentuk kekerasan yang diarahkan kepada perempuan hanya karena mereka perempuan. Melihat apa yang terjadi pada perempuan karena identitas kelaminnya, kemudian ia membagi bentuk tindakan tersebut meliputi :

1. Kekerasan fisik (physical abuse) seperti memukul dengan tangan atau senjata, menendang, menjambak, meludah, menusuk, menampar, mendorong, dan menonjok, merupakan bagian dari bentuk keerasan secara fisik.

2. Kekerasan psikis/emosional (emotional abuse), yaitu seperti rasa cemburu atau rasa memiliki yang berlebihan, mengisolasi diri dari lingkungan pertemanan dan sosial, mengancam diri untuk bunuh diri, mengancam kehidupan orang lain serta pasangan atau bisa melukai dan menganiaya orang disekitar atau orang terdekat, merusak barang-barang milik pribadi, melakukan pengawasan, manipulasi serta caci maki, melukai binatang peliharaannya, muncul perasaan takut melalui intimidasi, berbohong, ingkar janji, dan merusak hubungan dengan diri sendiri, orang tua saudara maupun anak.

3. Kekerasan ekonomi (economic abuse) seperti membuat tergantung terhadap ekonomi, dengan mengontrol terhadap penghasilan dan pembelanjaan yang tidak wajar, sehingga mengakibatkan tekanan terhadap pasangan.

4. Kekerasan seksual (sexual abuse), seperti tindak kekerasan yang memaksa perempuan menjadi pelacur, memaksa melakukan hubungan seks, menganiaya saat berhubungan seks, mendesak berhubungan seks setelah 
melakukan penganiayaan kepada lawannya, serta menggunakan binatang atau benda kasar saat berhubungan seks dan sebagainya. ${ }^{13}$

Kasus kekerasan dalam rumah tangga merupakan kasus yang paling banyak dijumpai dibandingkan dengan kasus kekerasan lainnya. Kekerasan dalam rumah tangga juga merupakan hal yang kompleks. Tidak seperti halnya kejahatan lainnya, dimana korban dan pelaku berada dalam hubungan personal, legal, institusional serta berimplikasi sosial. ${ }^{14}$ Perempuan yang dipukul oleh suaminya juga sama-sama membesarkan anak, mengerjakan pekerjaan dalam rumah, membesarkan keluarga, menghasilkan uang serta terikat secara emosional dengan pelaku kekerasan tersebut.

Realitas yang terjadi di Indonesia menunjukan beberapa kasus kekerasan dalam rumah tangga meningkat dari tahun ke tahun, dengan persentasi terbesar adalah kekerasan terhadap isteri. Sebagaimana dilaporkan oleh Komnas Perempuan yang dikutip oleh Elsa R.M. Toule, ${ }^{15}$ di Tahun 2007, dari 25.522 kasus kekerasan terhadap perempuan, sebanyak 17.722 kasus atau 69,6 persen adalah kekerasan terhadap isteri. Pada tahun 2008, angka ini meningkat lagi menjadi hampir 86 persen yakni sebanyak 46.884 dari keseluruhan kasus kekerasan terhadap perempuan sebanyak 54.525. Data tahun 2010 menunjukkan bahwa jumlah kekerasan terhadap istri tahun 2009 adalah sebesar 96 persen dari seluruh jumlah KDRT, yakni 131.375 kasus hingga menurut catatan akhir tahun 2014, terdapat 293.220 kasus kekerasan terhadap perempuan sepanjang tahun 2014. Sebanyak 68 persen dari kasus tersebut adalah kekerasan domestik dan rumah tangga (KDRT) dengan mayoritas korban ibu rumah tangga dan pelajar. ${ }^{16}$

Maggi Humm dalam pendapatnya mengatakan bahwa kekerasan terhadap perempuan merupakan sebuah tindakan dengan motif untuk mengontrol seksualitas perempuan dan peran reproduksi mereka, misalnya dalam ritual hubungan sosial, laki-laki sebagai pihak yang membutuhkan sementara perempuan sebagai obyek yang harus menerima apa kemauan laki-

\section{${ }^{13}$ Ibid, 131-132}

${ }^{14}$ Kathleen J. Ferraro, Woman Battering: More than Family Problem, dalam Women, Crime and Criminal Justice, (LA California: Claire Renzetti (Ed,), Roxbury Publishing Company, 2001), 135.

${ }^{15}$ Elsa R. M. Toule, "Kekerasan dalam Rumah Tangga, Kajian dari Perspektif Yuridis Kriminologis", http://fhukum.unpatti.ac.id/artikel/hukum-pidana/174-kekerasandalamrumah- tangga-kajian-dari-perspektif-yuridis-kriminologis - ftn2, diakses tanggal 18 November 2019, pukul 20.57

${ }^{16}$ Laraswati Ariadne Anwar, "Laporan KDRT Meningkat Penanganan Belum Optimal", dalam http://print.kompas.com/baca/2015/04/27/Laporan-KDRTmeningkat $\% 2 c$ Penanganan-Belum-Optimal, diakses tanggal 18 November 2019, pukul 20.59 
laki tanpa memperhatikan kondisi istri, ketika suami menginginkan dan ini tidak bisa terjadi sebaliknya. ${ }^{17}$

Faktor penyebab lain terjadinya kekerasan terhadap perempuan dalam rumah tangga, berakar dari adanya budaya patriarki. Budaya patriarki yang melihat garis keturunan dari ayah, secara tidak langsung membuat timbulnya pemikiran bahwa perempuan mempunyai posisi yang lebih rendah daripada laki-laki (subordinat). Perempuan dianggap sebagai mahluk lemah yang tidak mampu untuk melakukan apapun, dilecehkan, dikucilkan dan dikesampingkan, serta tidak mempunyai hak untuk menyuarakan apa yang ada dalam pikirannya. Perempuan sering disalahkan atas setiap kejadian buruk yang terjadi di keluarganya, di rumah tangganya. Perempuan pun pasrah apabila mendapat perlakuan yang kasar dari suaminya dan menganggap bahwa itu adalah hal yang wajar dilakukan oleh suaminya, karena memang ia yang menyebabkan semua itu terjadi. Perempuan selalu dituntut untuk meladeni apapun yang suaminya inginkan. Sementara laki-laki dianggap sebaliknya, yakni sebagai mahluk yang kuat, dapat melakukan apapun dan sebagainya. Budaya patriarki ini pun menyebabkan timpangnya relasi kuasa antara laki-laki dan perempuan. ${ }^{18}$

Dalam peneltian yang dilakukan oleh Kementerian Pemberdayaan Perempuan juga menunjukan bahwa hukum adat pada suatu daerah yang dapat menggantikan hukum nasional KDRT, menjadi faktor dalam memperlemah perlindungan yang dijanjikan bagi semua perempuan di Indonesia. Walaupun UU No. 23/2004 tentang KDRT telah dikeluarkan, namun di beberapa wilayah seperti Bali, misalnya, adat setempat bertentangan dengan Pasal 9 UU tentang KDRT, yang menyatakan bahwa orang dilarang "menciptakan ketergantungan ekonomi dengan cara membatasi atau melarang seseorang untuk bekerja secara layak di dalam ataupun di luar rumah".

Perempuan di beberapa kabupaten di Bali menyerahkan seluruh kepemilikannya kepada suami ketika menikah dan kehilangan segalanya ketika bercerai,. Perempuan Muslim juga kehilangan harta dan hak asuh atas anak-anak jika mengajukan perceraian karena digunakannya prinsip nusyuz: Pemerintah pusat perlu memastikan bahwa adanya konsistensi antara peraturan perundangan tingkat nasional dan daerah dalam hal perlindungan perempuan dari kekerasan dan penyiksaan. Masyarakat setempat harus diberdayakan untuk menuntut perlindungan dan pelayanan yang memadai.

Banyaknya perempuan yang kembali ke rumah di mana dimana mereka disiksa, menggambarkan perlunya strategi yang lebih terkoordinasi untuk memberikan pelayanan bagi laki-laki. Pusat Penanganan Krisis Perempuan Rifka Annisa di Yogyakarta memperkirakan bahwa 90\% 2007), 23.

${ }^{17}$ Maggi Humm, The Dictionary of Feminist Theory, (London: Harvests, Wheatsheaf,

${ }^{18}$ Kementrian Pemberdayaan Perempuan, Kekerasan Terhadap Perempuan-KDRT, (Jakarta: Kementerian Pemberdayaan Perempuan, 2002), 3 
perempuan kembali kepada suaminya setelah disiksa. Kenyataan ini menunjukkan terbatasnya upaya pemerintah untuk melakukan konseling terhadap laki-laki yang melakukan penyiksaan terhadap perempuan dalam kehidupannya. Di bawah UU KDRT tahun 2004, hakim dapat memerintah laki-laki untuk menjalani konseling, tapi program pemerintah sedikit jumlahnya dan tanggung jawabnya jatuh kepada organisasi masyarakat untuk menyediakan pelayanan ini dengan sumberdaya yang juga terbatas. ${ }^{19}$

Hal ini menunjukan sebuah fenomena yang cukup memprihatinkan, mengingat eksistensi untuk perempuan dalam rumah tangga haruslah diberikan kenyamanan. Namun kenyataannya masih banyak terjadi kekerasan dalam rumah tangga. Maka dari itu, penelitian ini berusaha untuk melihat penyebab dan mengkritik kontek kekerasan perempuan dalam rumah tangga yang terjadi pada baru-baru ini.

\section{Media Kumparan}

Media massa seperti media cetak, surat kabar, jaringan internet dan televisi memiliki sejumlah fungsi, penyampaian informasi atau pesan dan salah satu diantaranya memiliki fungsi cultural transmision. Berkaitan dengan fungsi ini, Walter Lippmann dengan ungkapan populernya "world outside and pictures in our heads", berpendapat bahwa media berfungsi sebagai pembentuk makna yang melalui interpretasinya mengenai berbagai peristiwa secara radikal dapat mengubah persepsi orang tentang suatu realitas dan pola tindakan mereka. ${ }^{20}$

Dewasa ini hal tersebut memungkinkan terjadi, sebab dalam pembelajaran sebelumnya menyangkut dengan konstruk media sosial, menampilkan sebuah cara pandang suatu media dalam menggambarkan realitas. Artinya jika demikian dikaitkan dengan fenomena konseptualisasi budaya dari lippman, maka pandangan terhadap realitas yang ditampilkan oleh media mengacu pada cara-cara tertentu berdasarkan terminologi pengetahuan yang kemudian di representasi

Opini yang dibangun oleh media merupakan bagian dari pemaknaan terhadap pikiran, ide serta konsep berasal dari sistem interpretasi simbol, teks, kata, dan bahasa. Ada dua hal yang menghubungkan representasi dan makna dalam sebuah kebudayaan, menurut Stuart yaitu. pertama, mental sebagai bagian dari representasi konsep tentang apa saja yang ada pada konseptual dalam bentuk secara abstrak. Kedua, bahasa memiliki peran penting dalam proses konstruksi makna, ide abstrak yang dikonsepkan dalam kepala harus mampu diterjemahkan kedalam bahasa verbal atau lazim, agar dapat menghubungkan.

19 Ibid., 4

${ }^{20}$ Hasyim Hasanah, Kekerasan Terhadap Perempuan dan Anak Perspektif Pemberitaan Media, Volume. 9, Cetakan ke-1, (Yogyakarta: Jurnal SAWWA, Oktober 2013), 168. 
Berkaitan dengan konsep tanda, ide dan simbol tertentu. Tahap pertama memungkinkan mengkonstruksi dan memaknai petunjuk konseptual suatu peristiwa melalui indra, sedangkan dalam tahap kedua, kita membingkai peta konseptual dan bahasa, yang memiliki fungsi representasi terhadap konsep-konsep. Hubungan peta konseptual, simbol serta bahasa adalah jantung dari produksi makna lewat bahasa. Pola yang memuat relasi ketiga elemen tersebut dengan bersama-sama itulah yang disebut representasi. Jika konsep tersebut dilakukan oleh media, maka makna yang diberikan dalam sebuah wacana cenderung tidak lepas dari persoalan ideologi media. ${ }^{21}$

Kumparan sebagai media baru yang menyajikan konten-konten berita yang unik dan berbeda dari jenis media yang lain, kemunculannya dalam situs instagram yang menarik perhatian khalayak mampu memuat pemberitaan yang singkat jelas padat dan tidak bertele-tele, kumparan didirikan oleh Budiono Darsono dkk, yang memiliki pandangan spesial tentang industri media online tanah air, menurutnya banyak perubahan yang telah terjadi pada konsumen berita di tanah air yang harus dicermati kembali dalam penggunaannya. Prinsip yang membedakan kumparan dengan media online pada umumnya adalah, prinsip mereka yang menganggap bahwa teknologi tidak sebagai pilar pendukung, melainkan teknologi sebagai fondasi utama. Inilah alasan mengapa kumparan memilih membuat platform yang mengkolaborasi konsep situs media sosial dengan berita. ${ }^{22}$

\section{Model Analisis Wacana Sara Mills}

Analisis berasal dari bahasa Yunani kuno yaitu "analusis" berarti melepaskan. Analusis terbentuk dari dua kata yaitu "and" yang berarti kembali dan "luein" yang berarti melepas. Menurut Kamus Besar Bahasa Indonesia, analisis adalah penyelidikan terhadap suatu peristiwa (karangan, perbuatan, dan sebagainya) untuk mengetahui keadaan yang sebenarnya. ${ }^{23}$ Analisis dapat diartikan sebagai sekumpulan kegiatan, aktivitas dan proses yang saling berkaitan untuk memecahkan masalah atau memecahkan komponen menjadi lebih detail dan digabungkan kembali untuk ditarik kesimpulan.

Kata wacana secara etimologi berasal dari bahasa Sansekerta wac/ wak/ vak berarti "berkata" atau "berucap". Sedangkan, kata -ana merupakan imbuhan berbentuk akhiran (sufiks) yang bermakna membedakan (nominalisasi). Kemudian kata tersebut digabung menjadi wacana yang diartikan sebagai perkataan atau tuturan. ${ }^{24}$ Namun, kata wacana ini diperkenalkan dan digunakan oleh ahli linguis di Indonesia sebagai

${ }^{21}$ Ibid, hlm. 171

22 Kumparan, Media Baru Unike Yang Langsung Melejit', Kumparan.com, Mey 21, 2019, diakses Mey 21, 2019, https://kumparan.com/suhari-ete/kumparan-media-baru-unikyang-langsung-melejit. diakses tanggal April 2019, pukul 08.30

${ }^{23}$ http://kbbi.web.id/analisis/, diakses pada 18 November pukul 08.52 WIB.

24 Alex Sobur, Analisis Teks Media, Suatu Pengantar Untuk. Analisis Wacana, Analisis Semiotik dan Analisis Framing, (Bandung: PT. Remaja Rosdakarya, 2012), 48. 
terjemahan dari bahasa Inggris, yaitu dari kata discourse. Kata discourse juga berasal dari bahasa Latin discursus yang berarti "lari kian- kemari". ${ }^{25}$ Secara teminologi, wacana memiliki pengertian yang luas mulai dari studi bahasa, psikologi, sosiologi, politik, komunikasi, dan sastra.

Menurut Kamus Besar Bahasa Indonesia, wacana mencangkup tiga hal. Pertama: ucapan, percakapan, dan tutur kata. Kedua: keseluruhan tutur atau cakap yang merupakan kesatuan. Ketiga: satuan bahasa terbesar, terlengkap dan terealisasi pada bentuk karangan utuh seperti novel, buku, dan artikel. ${ }^{26}$

Analisis wacana memiliki definisi yaitu studi tentang struktur pesan dalam komunikasi atau telaah mengenai aneka fungsi (pragmatik) bahasa. ${ }^{27}$ Bahasa yang dianalisis bukan hanya bahasa semata melainkan konteks dalam wacana tersebut. Konteks ini digunakan untuk tujuan dan praktik tertentu, termasuk praktik kekuasaan untuk memarjinalkan individu atau kelompok. ${ }^{28}$

Menurut Michel Foucault sebagaimana dalam buku yang ditulis oleh Eriyanto bahwa kajian analisis wacana tidak hanya dipahami sebagai serangkaian kata atau proposisi dalam teks saja tetapi kajian wacana merupakan sesuatu yang memproduksi suatu ide, opini, konsep, dan pandangan hidup dibentuk dalam suatu konteks tertentu sehingga mempengaruhi cara berpikir dan bertindak. ${ }^{29}$

Analisis wacana memiliki tiga pandangan dari segi bahasa. ${ }^{30}$ Pandangan pertama diwakili oleh kaum positivisme-empiris. Oleh penganut aliran ini, bahasa dilihat sebagai jembatan antara manusia dengan objek di luar dirinya. Pengalaman-pengalaman manusia dapat diekspresikan secara langsung melalui penggunaan bahasa tanpa ada kendala atau distorsi. Salah satu ciri pemikiran ini adalah ada pemisah antara pemikiran dan realitas. Pandangan ini terfokus pada kebenaran tata bahasa dan sintaksis. ${ }^{31}$

Pandangan kedua yaitu konstruktivisme. Pandangan ini menolak pemikiran positivisme-empiris yang memisahkan subjek dan objek bahasa. Konstruktivisme menganggap subjek sebagai kontrol terhadap maksudmaksud tertentu dalam setiap wacana. Bahasa dipahami sebagai pernyataanpernyataan yang dihidupkan. ${ }^{32}$

Pandangan ketiga adalah pandangan kritis. Pandangan ini menekankan pada kekuatan yang terjadi pada proses produksi dan reproduksi makna.

25 Ibid., 9

26 Peter Y Salim dan Yenny Salim, Kamus Besar Bahasa Indonesia Kontemporer, (Jakarta: Modern English Press, 2002), h. 1709

27 Alex Sobur, Op.cit., 72

${ }^{28}$ Aris Badara, Op.cit., 28 2001), 65

29 Eriyanto, Analisis Wacana, Pengantar Analisis Teks Media (Yogyakarta: LKiS,
${ }^{30}$ Aris Badara, Op.cit., $19-20$
${ }^{31}$ Ibid., 19
${ }^{32}$ Ibid., 19-20 
Bahasa dalam pandangan kritis dipahami sebagai representasi yang berperan dalam membentuk subjek, tema-tema wacana, maupun strategi- strategi didalamnya. ${ }^{33}$ Analisis wacana kritis dipakai untuk membongkar kuasa yang ada dalam setiap proses bahasa. Dalam penelitian ini, penulis menggunakan pandangan atau paradigma kritis.

Model gagasan analisis wacana dari Sara Mills sedikit berbeda dengan model critical linguistics, yang memusatkan perhatian pada struktur bahasa, dan menggambarkan bagaimana pengaruhnya dalam pemaknaan khalayak, dalam analisis ini sara mills melihatnya pada bagaimana posisi-posisi aktor ditampilkan dalam teks. Maksudnya adalah posisi ini yang berarti siapa yang menjadi subjek penceritaan dan siapa yang ditampilkan sebagai objek penceritaan, yang kemudian akan menentukan struktur teks dan bagaimana makna diperlakukan dalam teks secara keseluruhan, lebih jauh Sara Mills juga mencoba menekankan perhatiannya pada bagaimana pembaca dan penulis ditampilkan dalam teks.

Posisi ini akan berkaitan pada menempatkan pembaca dalam salah satu posisi dan mempengaruhi bagaimana teks tersebut hendak dipahami serta bagaimana aktor sosial ditempatkan. Dan akhirnya kita kan menemukan gambaran penceritaan serta melihat posisi-posisi yang ditampilkan dalam teks, membuat satu pihak menjadi legitimate dan pihak lain menjadi illegitimate. ${ }^{34}$

Untuk mengetahui kerangka analisis model Sara Mills, ada beberapa bagian yang menjadi poin penting agar dapat diperhatikan, serta bisa menentukan proses analisis lebih dalam, yaitu: Pertama, Posisi Subjek-Objek, yang coba ditampilkan adalah bagaimana peristiwa dilihat dari kacamata siapa yang diposisikan sebagai pencerita, serta siapa yang ditampilkan sebagai objek atau aktor yang diceritakan, kemudian apakah masing-masing dari keduanya yaitu pemain dan kelompok sosial memiliki kesempatan untuk menyampaikan gagasan dirinya sendiri, ataukah gagasan serta kehadirannya ditampilka oleh orang lain. Kedua, Posisi Penulis-Pembaca, disini sara mills akan memberikan gambaran bagaimana posisi pembaca berperan dan dimunculkan dalam teks, serta bagaimana pembaca menunjukan dirinya dalam teks yang ditampilkan kemudian kita mencoba mengetahui kepada kelompok manakah pembaca menempatkan dirinya. ${ }^{35}$

\section{E. Hasil dan Pembahasan}

Sara Mills dengan menggunakan analisis Althusser, lebih menekankan bagaimana posisi aktor ditampilkan dalam teks. Peran aktor dilihat sebagai bentuk pensubjekan seseorang, sehingga dalam perkembangannya suatu pihak mempunyai posisi sebagai penafsir sementara pihak lain menjadi objek

\footnotetext{
33 Ibid., 20

34 Eriyanto, Op.cit., 200.

35 Ibid, hlm. 201
} 
yang ditafsirkan secara umum, dalam analisis ini ada dua hal yang harus diperhatikan, pertama siapa pihak suatu aktor sosial yang diposisikan dalam pemberitaan, selanjutnya siapa pihak yang diposisikan sebagai penafsir dalam teks untuk memaknai peristiwa dan apa akibatnya, kedua bagaimana pembaca diposisikan dalam teks, dalam memposisikan teks berita akan dilihat bagaimana berita dimaknai sebagai hasil negosiasi antara pembaca dan penulis, disini akan terlihat khalayak seperti apa yang diharapkan oleh penulis untuk pembaca. ${ }^{36}$

\begin{tabular}{|c|c|}
\hline Tingkat & Yang Ingin Dilihat \\
\hline $\begin{array}{l}\text { Posisi Subjek-Objek } \\
\text { dan Posisi Penulis } \\
\text { Pembaca }\end{array}$ & $\begin{array}{l}\text { 1. Dalam wacana yang dimuat pada tanggal } 9 \text { maret 2019, } \\
\text { dengan judul sering ditanyai usai keluar rumah, suami } \\
\text { aniaya istri hingga tewas, penulis menampilkan pelaku sebagai } \\
\text { subjek yang mengeluh akan apa yang dilakukan sang istri } \\
\text { kepadanya, hal ini terlihat pada judul diatas dan juga pada } \\
\text { kalimat yang mengungkapkan bahwa pelaku memukul, } \\
\text { menendang dan membanting korban, dikarenakan istrinya } \\
\text { selalu menegur dirinya saat keluar rumah, dan puncaknya } \\
\text { pada hari dimana ia berlaku kasar dan langsung memukuli } \\
\text { korban hingga tewas, sedangkan perempuan/istri pelaku } \\
\text { dalam pemberitaan tersebut, ditampilkan sebagai objek, } \\
\text { yakni menjadi korban usai percekcokan hingga pelaku } \\
\text { berlaku keras dan menewaskan sang istri ia, dalam } \\
\text { kaitannya dengan posisi penulis dalam pemberitaan ini, } \\
\text { menunjukan bahwa penulis menggambarkan secara rinci } \\
\text { dan singkat kekerasan yang menimpa si perempuan, serta } \\
\text { mengungkapkan secara gamblang dengan menghadirkan } \\
\text { saksi dalam peristiwa tersebut, sehingga dalam kejadian ini, } \\
\text { penulis ingin menyuarakan apa yang dirasakan atau } \\
\text { menimpa si perempuan sampai ia tewas, sedangkan pada } \\
\text { posisi pembaca yang direpresentasikan pada pemberitaan } \\
\text { tersebut, menunjukan bahwa yang mengonsumsi berita } \\
\text { itu adalah laki-laki yang dikarenakan emosi kepada istri } \\
\text { bila terjadi adu mulut mengakibatkan hal demikian, namun } \\
\text { juga secara tidak langsung pembaca perempuan } \\
\text { ditampilkan sebagai perempuan yang selalu bertanya } \\
\text { kepada suami akan mampu memancing amarah sang } \\
\text { suami. } \\
\text { Wacana yang berjudul “ belum } 3 \text { bulan, ada } 7 \text { kasus kekerasan } \\
\text { terbadap perempuan" secara langsung menampilkan } \\
\text { perempuan sebagai subjek yang menginformasikan apa }\end{array}$ \\
\hline
\end{tabular}

${ }^{36}$ Eriyanto, Analisis Wacana, Pengantar Analisis Teks Media, Op.cit., 210 


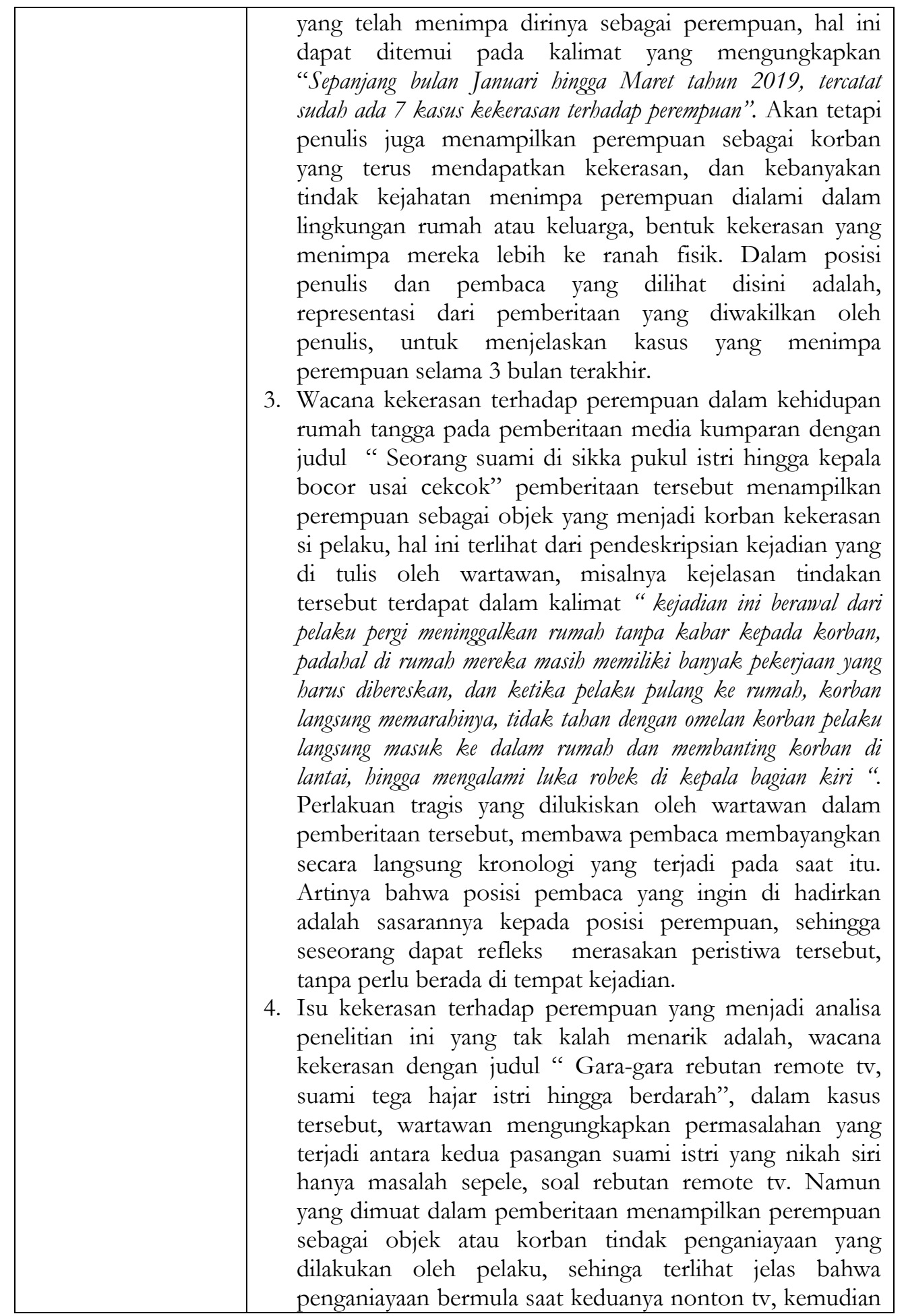




\begin{tabular}{|l|l|}
\hline rebutan remote tv, hingga kemudian terjadi cekcok mulut, \\
pelaku semula hanya mencubit dan meremas tangan \\
istrinya, karena kesakitan korban berontak, saat itulah \\
pelaku semakin menjadi dan memukuli istrinya dengan \\
tangan kosong sampai membenturkan kepala korban di \\
dinding, akibat penganiayaan tersebut korban mengalami \\
luka robek di pelipis kirinya dan luka memar karena \\
dibenturkan ke dinding. Penulis mempresentasikan dirinya \\
sebagai subjek yang mewakili korban dalam penganiayaan \\
tersebut, sehingga pemberitaan disampaikan seperti \\
korban yang menulis atau menginformasikan secara \\
langsung apa yang menimpa dirinya. \\
5. Selanjutnya isu tentang kekerasan terhadap perempuan \\
dalam lingkungan rumah tangga dengan judul berita “ \\
Aniaya istri dan anak pakai pisau, pria di pasuruan di \\
amankan" dalam mengungkap kasus tersebut, wartawan \\
sebagai penulis berita ini, memposisikan perempuan \\
sebagai objek yang teraniaya oleh pelaku, pelaku sendiri \\
sudah berulang kali melukai sang istri dengan tiga kali \\
tusukan pisau diperutnya, Aksi sadis itu disebut-sebut \\
lantaran adanya keributan berujung ungkapan perceraian, \\
yang tidak diinginkan oleh pelaku” kasus ini menunjukan \\
awal mulanya korban sudah meminta cerai kepada suami, \\
namun karena tidak terima pernyataan cerai tersebut, \\
akhirnya sang suami bertindak kasar menganiaya istri dan \\
bahkan anaknya pun ikut ditusuk dengan pisau. Posisi \\
yang ditampilkan dalam tulisan ini menunjukan Penulis \\
secara langsung merepresentasikan atau mewakili korban \\
dalam mengungkapkan kejadian yang ia alami, sasarannya \\
pun lebih kepada pembaca perempuan yang ikut terlibat \\
merasakan kisah pilu tersebut. \\
\hline
\end{tabular}

Hasil penelitian menunjukan, penulis menampilkan perempuan sebagai objek dan subjek pemberitaan, karena perempuan dalam posisi teks diatas dapat menampilkan atau menceritakan apa yang menimpa dirinya. Sedangkan objek disini, perempuan mendapatkan perilaku tidak senonoh atau kasar dari sang suami, baik itu dalam bentuk pukulan, adu mulut, hingga tusukan pisau berulang kali yang menimpa perempuan.

Berdasarkan hasil analisa yang dilakukan dalam media Kumparan, menunjukan bahwa media tersebut lebih mengutamakan memperlihatkan perempuan sebagai korban yang teraniaya dengan segala bentuk tindak kekerasan, meskipun di beberapa pemberitaan ada juga perempuan ditampilkan sebagai subjek yang mencerminkan keberpihakan dalam memberikan perhatian penting kepada kaum perempuan, sebagaimana 
ditemui pada konten-konten kumparan, yang menghadirkan konten women/perempuan dan anak secara khusus.

\section{Kesimpulan}

Dari hasil penjelasan di atas, penerapan analisis wacana kritis model sara mills, yang lebih menekankan pada konsep feminisme erat kaitannya dengan kesetaraan pria dan wanita dalam berbagai aspek kehidupan, sehingga dalam perkembangannya model sara mills ini digunakan sebagai alat analisis wacana terhadap pemberitaan media menyangkut dengan isu-isu keperempuanan, kekerasan dalam rumah tangga, pelecehan seksual dan sebagainya.

Dalam tahap ini, sebagaimana yang diinginkan oleh sara mills, bahwa perempuan harus mendapatkan perlakuan yang pantas serta memperoleh kesetaraan yang sama dengan laki-laki baik itu dari segi pendidikan, politik maupun lingkungan keluarga, bahkan dari aspek pemberitaan media yang harus menyetarakan pemberitaan perempuan sebagaimana mestinya. Sehingga model analisis ini dapat mengungkapkan posisi seperti apa yang ditekankan media dalam pemberitaan tersebut.

\section{Daftar Pustaka}

Anwar, Laraswati Ariadne, Laporan KDRT Meningkat Penanganan Belum Optimal, dalam http://print.kompas.com/baca/2015/04/27/Laporan-KDRTmeningkat \%2cPenanganan-Belum-Optimal, diakses tanggal 18 November 2019, pukul 20.59

Aris Badara, (2013), Analisis Wacana: Teori, Metode dan Penerapannya Pada Wacana Media, Jakarta: Kencana Prenada Media Group.

Eriyanto, (2001), Analisis Wacana, Pengantar Analisis Teks Media, Yogyakarta: LkiS.

Ferraro, Kathleen J., (2001), Woman Battering: More than Family Problem," dalam Women, Crime and Criminal Justice, LA California: Claire Renzetti (Ed,), Roxbury Publishing Company.

Hasanah, Hasyim, (2013), Kekerasan Terhadap Perempuan dan Anak Perspektif Pemberitaan Media, Volume. 9, Cetakan ke-1, Yogyakarta: Jurnal SAWWA.

Hasbi, Muhammad, (2015), Kekerasan Perempuan Dalam Wacana Agama dan Sosiologi, Volume. 15, Cetakan ke-2, Ponorogo: Jurnal Al-Tahrir. 
Kementrian Pemberdayaan Perempuan, (2002), Kekerasan Terhadap PerempuanKDRT, Jakarta: Kementerian Pemberdayaan Perempuan.

Muhajarah, Kurnia, (2016), Kekerasan Terhadap Perempuan Dalam Rumab Tangga Perspektif Sosio-Budaya, Hukum dan Agama, Volume. 11, Cetakan ke-2, Semarang: SAWWA.

Nawawi, Hadari, (1991), Metode Penelitian Bidang Sosial, (Yogyakarta: Gajah Mada University Press

Prantya, Shella Yan, (2017), Marjinalisasi Perempuan Dalam Berita Pelecehan Seksual Surat Kabar Harian Memorandum Edisi September 2013 Dan Juli 2015: Analisis Wacana Kritis Sara Mills, Volume 01 Cetakan ke-1, Surabaya: Jurnal BAPADA.

Rahmat, Jalaluddin, (1999), Metode Penelitian Komunikasi, (Bandung: Remaja Rosdakarya.

Ratna, Nyoman Kutha, (2010), Metodologi Penelitian: Kajian Budaya dan Ilmu Sosial Humaniora, Yogyakarta: Pustaka Pelajar

Salim, Peter Y., dan Yenny Salim, (2002), Kamus Besar Bahasa Indonesia Kontemporer, Jakarta: Modern English Press.

Sobari, Teti, dan Lilis Faridah, (2016), Model Sara Mills Dalam Analisis Wacana Peran Dan Relasi Gender, Volume 5, Cetakan ke-1, Siliwangi: SEMANTIK: Jurnal Ilmiah Program Studi Pendidikan Bahasa dan Sastra Indonesia.

Sobur, Alex, (2012), Analisis Teks Media, Suatu Pengantar Untuk. Analisis Wacana, Analisis Semiotik dan Analisis Framing, (Bandung: PT. Remaja Rosdakarya.

Sodik, Mochamad, (2012), Kesetaraan Gender Sebagai Pemenuban Konstitusi, Volume 11, Cetakan ke-2, Yogyakarta: Jurnal Musãwa.

Tanesia, Rosa Oktaviani, (2013), Wacana Mengenai Human Trafficking Dalam Film "Jamila Dan Sang Presiden", Volume. 1, Cetakan ke-2, (Surabaya: Jurnal EKomunikasi.

Wirawan, Prasetya, (2000), Logika dan Prosedur Penelitian, Jakarta: CV Infomedika.

Zubaedah, Siti, (2010), Mengurai Problematika Gender Agama, Volume. 5, Cetekan ke-2, Purwokerto: YINYANG, Jurnal Studi Gender \& Anak.

\section{Internet}


http://kbbi.web.id/analisis/, diakses pada 18 November pukul 08.52 WIB.

Humm, Maggi, (2007), The Dictionary of Feminist Theory, London: Harvests, Wheatsheaf.

Kumparan, Media Baru Unik Yang Langsung Melejit, Kumparan.com, Mey 21, 2019, diakses Mey 21, 2019, https://kumparan.com/suhari-ete/kumparanmedia-baru-unik-yang-langsung-melejit diakses tanggal 13 April 2019.

Toule, Elsa R. M., "Kekerasan dalam Rumah Tangga, Kajian dari Perspektif Yuridis Kriminologis”, $\quad$ http://fhukum.unpatti.ac.id/artikel/hukum-pidana/174kekerasan-dalamrumah- tangga-kajian-dari-perspektif-yuridis-kriminologis - ftn2, diakses tanggal 18 November 2019, pukul 20.57 